\title{
Hydrological system analysis and modelling of the Nam Co basin in Tibet
}

\author{
P. Krause, S. Biskop, J. Helmschrot, W.-A. Flügel, S. Kang, and T. Gao \\ Department for Geoinformatics, Hydrology and Modelling, Friedrich-Schiller-University, Jena, Germany \\ Received: 16 February 2010 - Revised: 15 August 2010 - Accepted: 17 August 2010 - Published: 25 August 2010
}

\begin{abstract}
The Tibetan Plateau and the adjacent high mountain regions of the Himalayas play an important role in the global climate dynamic through its impact on the Asian monsoon system, which in turn is impacting the water resources of this extremely vulnerable region. To provide further knowledge about the changing impact of rainfall patterns, spatial and temporal variability of snow cover contribution, amount of snow and ice melt runoff, evapotranspiration as well as dynamics of wetlands and permafrost water balance studies are required. This is of particular importance in terms of global climate change because of a severe gap in the knowledge of the short, mid and long term implications on the hydrological system.

This study concentrates on the macroscale catchment of the lake Nam Co, located at $4718 \mathrm{~m}$ a.s.l. at the foot of the Nyainqentanglha Mountains in central Tibet $\left(30^{\circ} \mathrm{N}, 90^{\circ} \mathrm{E}\right)$. The water balance of the Nam Co basin is dominated by semi-arid climate, snow and ice melt runoff and high evaporation rates due to the high radiation input and the low air humidity. The observed temperature rise, glacier retreat, permafrost decay and lake level increase indicate significant system changes and the high sensitivity of the Tibetan Plateau on global warming. The development of a suitable water balance model and its preliminary application was the main objective of this study. The development was done with the Jena Adaptable Modelling System JAMS along with existing scientific process components of the J2000 module library which were partly further developed to reflect the specific conditions of the high elevation Nam Co basin.

The preliminary modelling exercise based on gridded data from a downscaled ECHAM5 data set provided reasonable estimates about the important hydrological water balance components of the Nam Co basin. With the modelling results the observed lake level rise could be reproduced and it could
\end{abstract}

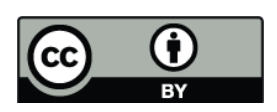

Correspondence to: $\mathrm{P}$. Krause (p.krause@uni-jena.de) be shown that the runoff from the glaciered areas seems to be the most important component to explain the increasing amount of lake water.

\section{Introduction}

The Tibetan Plateau is a key area within the earth system and is outstandingly relevant for the global climate dynamics due to its huge extension on high altitudes and the resulting importance for the Asian monsoon system. Although there have been many investigations on parts of this complex ecosystem in the recent past, knowledge about physiographical processes and todays anthropogenic impact on the Tibetan ecosystem and its spatial and temporal dimensions is still limited. In the last decades a number of research studies investigated parts of the global change impact on the Tibetan Plateau and presented results about climate development ( $\mathrm{Yu}$ et al., 2001; Treydte et al., 2006; Wang and Ding, 2006; Wu et al., 2006), glacier retreat (Thompson et al., 2003; Ye et al., 2006), lake hydrology (Cyranoski, 2005), and vegetation patterns (Chen et al., 2005; Zhou et al., 2006a).

The mean temperature on the Tibetan Plateau increased by $0.02^{\circ} \mathrm{C}$ per year during $1971-2000$ (Wu et al., 2007), which is much faster than the global average of $0.74{ }^{\circ} \mathrm{C}$ total over the last 100 years (Solomon et al., 2007). Temperature projections for the 21 st century predict that the temperature on the Tibetan Plateau will rise by $2.5^{\circ}$ until 2050 and $5^{\circ} \mathrm{C}$ until 2100 (Rupa Kumar et al., 2006). In contrast to an increasing temperature trend over the entire Tibetan Plateau, several studies show spatial variability in precipitation trends. Most regions, especially the eastern and central part of the Tibetan Plateau, have become wetter over the past several decades, while the western part has become drier (Xu et al., 2008). Changes in extreme precipitation indices show increasing trends in the southern and northern Tibetan Plateau but decreasing trends in the central Tibetan Plateau (You et al.,

Published by Copernicus Publications on behalf of the European Geosciences Union. 


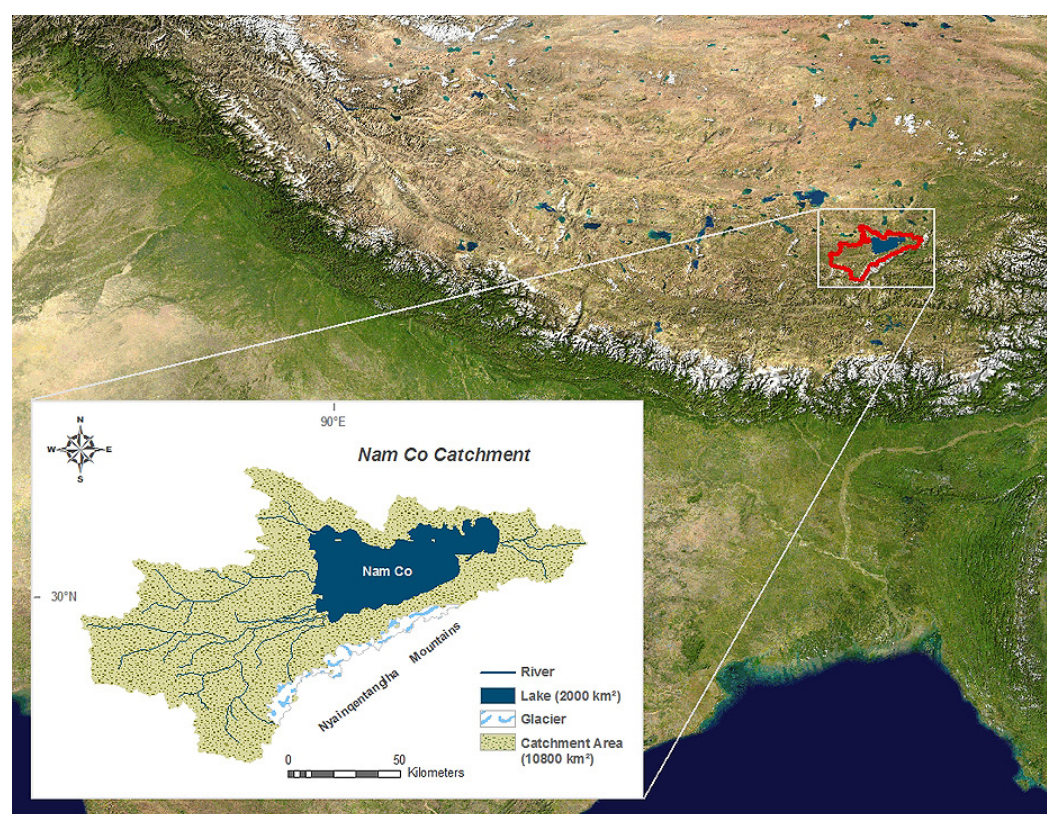

Fig. 1. Nam Co basin test site and its position on the Tibetan Plateau.

2010). The prediction of effects of climate change on the summer monsoon rainfall is very uncertain due to the local topographic characteristics causing a high spatial and temporal variability of rainfall.

Changing precipitation and evapotranspiration rates are directly affecting the amount of available water for runoff generation. Due to rising temperatures more precipitation will fall as rain instead of snow which will lead to short and long term storage decreases. In consequence the majority of glaciers on the Tibetan Plateau were retreating dramatically during the last decades. In the last 40 years the glaciers on the Tibetan Plateau shrank by $7 \%$, with a decrease of $4.5 \%$ during the last 20 years (CNCCC, 2007). Projections of glacier retreat suggest that glacier shrinkage will accelerate significantly with continuing global warming (Solomon et al., 2007) which will affect the hydrological regime of river basins originating in the Himalayas: first by increasing discharge due to accelerated melting rate, and subsequently by decreasing stream flow much lower than at present as glacier water storage is reduced (Eriksson et al., 2009).

Field observations on the Zhadang glacier south of the lake Nam Co showed that the glacier mass balance in this region is not only influenced by the air temperature, but is also strongly affected by the precipitation seasonality - significantly more than by the annual amount (Kang et al., 2008). The mass balance in the years 2005/2006 and 2006/2007 of Zhadang glacier was strongly negative caused by higher air temperature and lower precipitation during the ablation period resulting in distinct glacier melt runoff (Kang et al., 2008). However, the lower summer temperature and higher precipitation in the early stages of the ablation season in May and June 2008 led to an increasing mass balance and relatively low and constant river runoff from the glacier terminus. Chen et al. (2008) assessed that between 1970 and 2007 the glacier area of the Nam Co basin decreased by $37.1 \mathrm{~km}^{2}$. In the same period the area of Nam Co lake increased by $72.6 \mathrm{~km}^{2}$.

Lake fluctuations are investigated on the Tibetan Plateau in the last 30 years. Ye et al. (2008) found both - lake size decreases and increases - of lakes in the Mapam Yumco basin in western Tibet between 1974 and 2003. Bianduo et al. (2009) monitored four smaller lakes in the vicinity of the Nam Co using Landsat TM and CBERS data. They reported lake area increases since 1975 with accelerating speed in 2000-2005. Lake level changes obtained by satellite altimetry were published by Maheu (2003); Berry et al. (2005); Harrison et al. (2006). The Nam Co lake level is observed since 2005 during ice free periods (May-October) (You et al., 2006; Zhou et al., 2006b). Zhou et al. (2006b) concluded that the lake level rise of $36 \mathrm{~cm}$ from May to mid September 2005 was caused by higher rainfall and melting snow during the summer season, whereas less precipitation and retention of water in ice and snow cover indicated a lower input which led to a $10 \mathrm{~cm}$ lake level decrease in autumn.

Although there have been many investigations on parts of the complex ecosystem of the Nam Co basin in the recent past, comprehensive hydrological system dynamic studies or hydrological model simulations to estimate the water balance are missing. Adequate knowledge about the interrelated hydrological system components and processes is still limited, 
especially on their spatial and temporal dimensions. Böhner (2006) stated that water balance estimates are still afflicted with major uncertainties due to methodological limits in the spatial estimation of rainfall rates and widely lacking evapotranspiration records, particularly on the Tibetan Plateau and adjacent high mountain systems. Distributed, processoriented hydrological modelling can provide further knowledge about the complex process interactions on the Tibetan Plateau.

\section{Study site lake Nam Co}

The lake Nam Co $\left(30^{\circ} \mathrm{N} / 90^{\circ} \mathrm{E}, 4718 \mathrm{~m}\right.$ a.s.l. $)$ is the largest lake in Tibet and the biggest lake in the world in that height. It is located at the foot of the north slope of the Nyainqentanglha Mountain in central Tibet. The lake itself covers an area of approx. $2000 \mathrm{~km}^{2}$ with a drainage basin of about $11000 \mathrm{~km}^{2}$ (Fig. 1).

The Institute of Tibetan Plateau Research, Chinese Academy of Sciences (ITP-CAS), operates a research station at the eastern end of the lake. Here, climatological observations as well as measurements of runoff and lake level fluctuations are undertaken since 2005 (Kang et al., 2008; Zhou et al., 2006b). Additionally, some climate measurements as well as snow and ice hydrological data are available from Zhadang glacier, located at the north-eastern slope of Mt. Nyainquentanglha. Here, in 2005 two automatic weather stations (AWS) were set up at elevations of 5400 and $5800 \mathrm{~m}$ a.s.l., complemented by the installation of a rain gauge near the terminus in May 2007.

The climate of the Nam Co region is located at the intersection of the Westerlies, the winter monsoon, the South West Asian monsoon, and the East Asian monsoon (Kang et al., 2007). During the summer months (June-September) the Nam Co basin is controlled by the Indian Monsoon, while dominated by Westerlies during the dry winter season. The Nam Co basin features semi-arid subarctic plateau climate according to the climate classification developed by the Chinese Meteorological Adminstration (Liu, 1998). At the Nam Co the annual mean temperature was measured as $0^{\circ} \mathrm{C}$ with a large daily and seasonal variability (Zhang et al., 2008). The highest monthly temperature is about $10^{\circ} \mathrm{C}$ and the lowest around $-12{ }^{\circ} \mathrm{C}$. The large diurnal temperature gradient (absolute maximum and minimum temperatures were observed as $20.6^{\circ} \mathrm{C}$ and $-30.3{ }^{\circ} \mathrm{C}$ ) indicates the strong continentality of the area. The Nam Co basin is located in the rain shadow of the Himalayas and the annual precipitation is estimated as about $300-500 \mathrm{~mm}$ occurring mainly during the summer monsoon season (Zhu et al., 2004). The annual precipitation amount at Nam Co station from 2005 to 2008 was measured as $415 \mathrm{~mm}$ (Zhang et al., 2008).

\section{Material and methods}

\subsection{Input data}

The Chinese project partner of the Institute of Tibetan Plateau Research (ITP) provided hydro-meteorological data measured at the Nam Co research station for the time period 2005-2008. These measurements include air temperature, radiation, wind speed and direction, precipitation, air pressure and relative humidity. Apart from the Nam Co station no other station is located within the study area. Data from other meteorological stations outside the Nam Co basin south of Nyainqentanglha Mountains in the Brahmaputra region was found not to be representative for the study area because the Nam Co region features significantly colder and drier conditions. Because of the limited availability of observed data, gridded global and regional climate projections had to be used to provide driving data for the hydrological modelling. For this purpose a downscaled ECHAM5 data set (Ahrens and Dobler, 2008) generated with a combined (dynamical and statistical) downscaling approach was used. Since the gridded climate data provided only precipitation, temperature and wind speed as direct climate input variables, relative humidity and sunshine hours had to be derived. Relative humidity was estimated from temperature and dew point temperature; sunshine hours were derived from cloud cover and potential sunshine duration.

To assess the quality of the climate variables, the data set was compared to another gridded climate data set from the Climate Research Unit (CRU) and to observed data from the Nam Co station. The comparison of gridded temperature and precipitation values from downscaled ECHAM5 und CRU for the time period 1961-2000 showed that (1) the projected temperatures had a high agreement whereas precipitation data were less correlated, (2) precipitation of the ECHAM5 data set was significantly higher than the precipitation of the CRU data sets, (3) both data sets showed the same trends with more or less the same magnitude. The comparison of the gridded data with measured data of the Nam Co research station showed a reasonable accordance but also discrepancies which will have to be investigated in more detail in the future. For this first study only the downscaled ECHAM5 data were used. They were considered to be sufficient for the estimation of the long term water balance of the Nam Co basin.

\subsubsection{The model J2000g}

For this study, the J2000g model (Krause and Hanisch, 2009) was used which was developed for historical simulations as well as for long term hydrological projections. This model was adapted from the J2000 model (Krause, 2001, 2002) and implemented within the JAMS modelling framework system (Kralisch and Krause, 2006) and can be categorised as a spatially distributed conceptual hydrological model with a minimum number of calibration parameters. The model J2000g 
requires spatially distributed information related to topography, land use, soil type and hydrogeology to estimate specific attribute values for each modelling unit. J2000g also requires meteorological inputs (precipitation, minimum as well as average and maximum temperature, sunshine duration, wind speed, and relative humidity). From this input data net radiation and the potential evapotranspiration (PET) according to the Penman-Monteith approach is calculated using the methods presented in Allen et al. (1998).

Snow accumulation and snow melt are simulated with a day-degree approach followed by a soil moisture accounting module consisting water storage with a capacity defined from the field capacity of the specific soil type within the respective modelling unit. Soil water storage is only emptied by evapotranspiration uptake. The actual evapotranspiration is determined by the saturation of the soil water storage, the potential evapotranspiration and a calibration coefficient. The runoff is generated only when the soil water storage is at saturation and partitioned into direct runoff and percolation based on the slope of the modelling unit and the underlying hydrogeology. The percolation component is transferred to a groundwater storage and then into baseflow by a linear storage approach. The total streamflow of a catchment results from the summation of the direct runoff and the baseflow components from each modelling unit.

For this specific project two additional modules were implemented into $\mathrm{J} 2000 \mathrm{~g}$ - a glacier module and a lake module. The glacier module is based on the method of Hock (2005) which calculates melt from snow and ice using a degree-dayfactor approach. The lake module considers lake evaporation according to Penman (1948) and is tracking the volume changes that result from the hydrological dynamics in the lake basin.

When using gridded climate input data as drivers for distributed modelling one has to make sure that the mass and energy balances of the data set are preserved in the modelling results. This was considered by assigning each modelling unit exactly one climate data grid cell and passing the climate data to the modelling unit without further interpolation or regionalisation. The disadvantage of this approach is the insufficient representation of small or regional scale climate patterns. In terms of the Nam Co basin this is of particular importance for the mountain range in the south. In these parts elevation controlled gradients in temperature, rainfall and other weather elements could not be fully represented.

\subsection{Catchment distribution}

Due to the limited data availability a simple catchment distribution was used in this study. Unlike the traditional HRUconcept which is normally used with J2000g, simplified modelling entities were created by overlay of the grid cells from the downscaled ECHAM5 data and land cover types (lake, glacier, land surface). Figure 2 shows the lake basin and the coarse modelling entities.

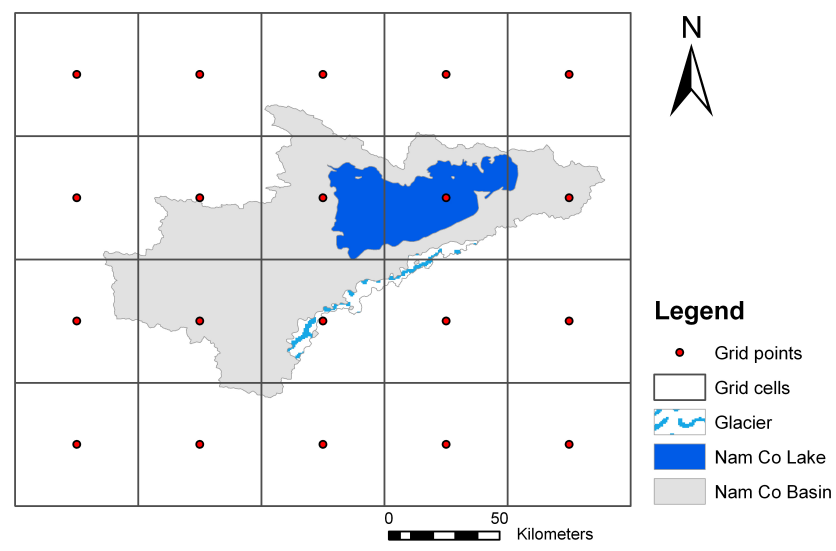

Fig. 2. Simplified spatial distribution of modelling units and climate grid cells.

The entire basin was distributed into 21 modelling units with areas between 5 and $2000 \mathrm{~km}^{2}$. The land surface was represented by 15 modelling units with an average elevation of $5060 \mathrm{~m}$ a.s.l., the lake surface was composed of three modelling units with an average elevation of $4725 \mathrm{~m}$ a.s.l. and the glaciered area was represented by three response units with an average elevation of $5600 \mathrm{~m}$ a.s.l. For each modelling unit elevation, slope, aspect, dominant land cover and soil type was defined using GIS and provided as a J2000g compliant parameter file.

\subsection{Model setup and calibration}

Due to the lack of long term observation data of streamflow or lake volume the model was not calibrated for the Nam Co basin. Moreover, model parameters obtained in an alpine catchment in Austria were transferred and used for the Nam Co with only one minor adaptation. That means the base temperature parameter which controls the melt of the snow and glacier was increased to a value of $5.5^{\circ} \mathrm{C}$ to compensate the insufficient spatial resolution of the gridded climate data. Without such adaptation the runoff from glaciers would have been much too high in summer times.

\section{Results and discussion}

With the J2000g model of the Nam Co catchment a long term mean annual air temperature of $-1.7^{\circ} \mathrm{C}$ for the period of November 1961 to October 2010 was simulated. The coldest year was estimated with $-4.5^{\circ} \mathrm{C}$, the warmest with $0{ }^{\circ} \mathrm{C}$. The mean annual precipitation was estimated as $526 \mathrm{~mm} / \mathrm{yr}$ with a range between 409 and $661 \mathrm{~mm} / \mathrm{yr}$. Relative humidity was calculated as $53 \%$ in the long term mean varying between 44 and $66 \%$. The potential ET was calculated as $685 \mathrm{~mm} / \mathrm{yr}$ whereas the actual ET was estimated to be $520 \mathrm{~mm} / \mathrm{yr}$. The mean total annual amount of water generated on the nonglaciered land surface flowing into the lake was simulated 
to be $4.48 \mathrm{~km}^{3} / \mathrm{yr}$. The mean total annual amount of water from the glaciered areas was computed as $7.12 \mathrm{~km}^{3} / \mathrm{yr}$ whereas the lake balance (without inflows) was negative with $-4.67 \mathrm{~km}^{3} / \mathrm{yr}$. These numbers indicate the likely importance of the glacier dynamics for the observed lake level rise.

The trend analysis of the modelling results reproduced the patterns already discussed in the literature (e.g. Kang et al., 2008). To quantify whether trends are significant or not a signal to noise ratio (SNR) was calculated as the ratio between the trend and the standard deviations of the anomalies. SNR values of larger than 1 are assumed to show a significant trend (Bormann, 2005).

Annual precipitation showed no significant trend over the period of 1961-2010. The mean air temperature showed a non-significant (SNR 0.92) increasing trend which amounted to $0.69^{\circ} \mathrm{C}$ in the $50 \mathrm{yr}$ period. A significant increasing trend (SNR 1.15) of $+6 \%$ was also found for relative humidity. The other climate variables and also the potential (PET) and actual evapotranspiration (AET) did not show significant trends. The land surface runoff showed a decreasing trend which was not significant (SNR 0.78). A significant (SNR 1.27) increasing trend was found for the simulated glacier runoff and related to the fact that a significant (SNR 1.23) decreasing trend for the average glacier mass balance was calculated. The annual anomalies calculated by the subtraction of the 1960-1990 mean from the annual sums or means are shown in Fig. 3.

The analysis of the single decades between 1961 and 2010 showed that the first decade (1961-1970) was very wet with a precipitation of about $18 \mathrm{~mm} / \mathrm{yr}$ above average whereas the following decade was very dry with a precipitation of $15 \mathrm{~mm} / \mathrm{yr}$ below average. The following three decades showed average rainfall amounts with anomalies between -5 and $+2 \mathrm{~mm} / \mathrm{yr}$. The first and the third decade showed colder temperatures of about $-0.3{ }^{\circ} \mathrm{C}$ below average whereas the last two decades from 1991 to 2010 were both about $0.3^{\circ} \mathrm{C}$ warmer than the average. The second decade was slightly warmer $\left(+0.08^{\circ} \mathrm{C}\right)$ than the long term average.

The simulated actual evapo(transpi)ration (AET) values for the decades show relatively constant values for the lake evaporation between 738 and $755 \mathrm{~mm} / \mathrm{yr}$ which is close to the value of $760 \mathrm{~mm} / \mathrm{yr}$ reported by Morrill (2004) for the lake Ahung Co which is about $150 \mathrm{~km}^{2}$ from Nam Co on the same elevation. Evapotranspiration from land surface without glaciers is much lower due to the limited water availability. It was estimated as $482 \mathrm{~mm} / \mathrm{yr}$ for the entire period, with a minimum value of $467 \mathrm{~mm} / \mathrm{yr}$ in the second decade and a maximum value of $501 \mathrm{~mm} / \mathrm{yr}$ at the end of the simulation period. During the entire $50 \mathrm{yrs}$ a slight increase of AET on land surface was calculated. The AET from the glaciered areas was estimated as only $55 \mathrm{~mm} / \mathrm{yr}$ stemming from sublimation from the snow cover. When the glaciers are snow free the model assumes that no evaporation occurs. Figure 4 shows the AET values for the five decades and the three different land cover types.

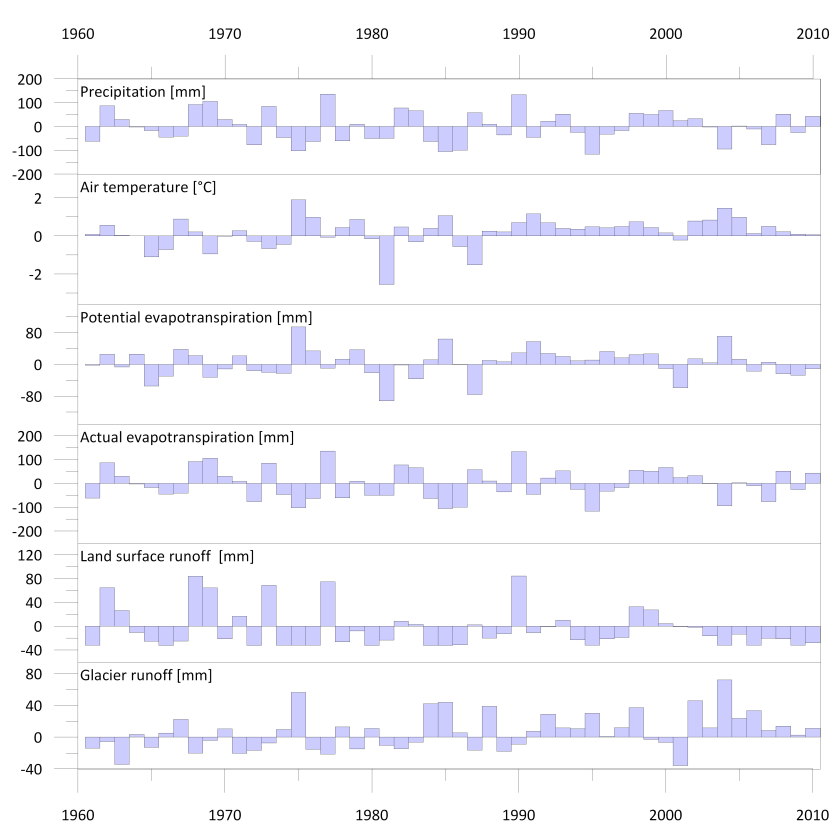

Fig. 3. Mean basin wide annual anomalies (from 1960-1990 mean) of various climate and water balance terms.

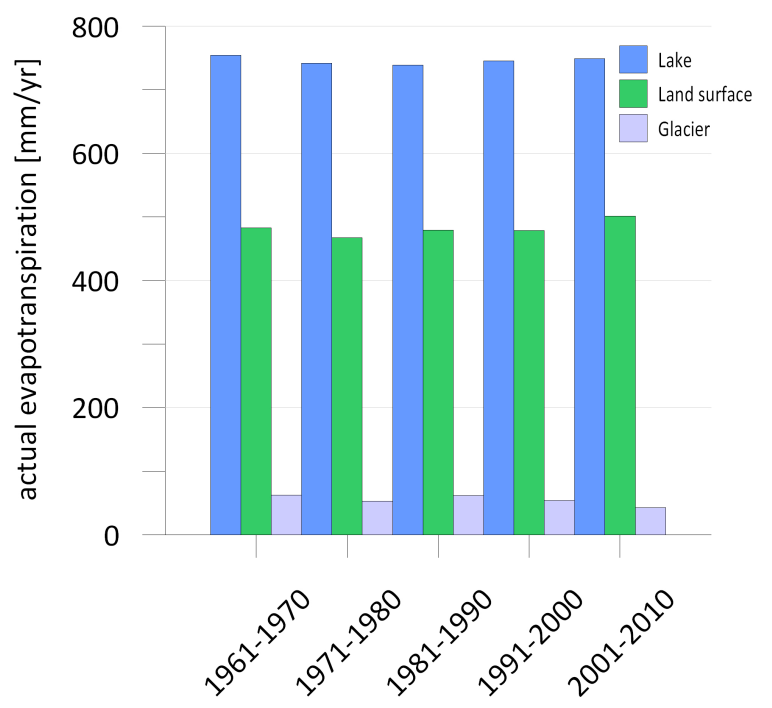

Fig. 4. Actual evaporation rates for the five simulated decades and the three different land cover types.

On the basis of precipitation, actual evapotranspiration as well as snow and glacier melt the runoff generation was calculated by $\mathrm{J} 2000 \mathrm{~g}$ for the three different land cover types land surface, lake surface and glaciers. In this simplified model it is assumed that the entire runoff generated on one of these land cover types is contributing directly to the lake Nam Co.

The largest contribution to the lake water volume was computed from the glaciered areas. This is even more important taking into account that only about $4 \%$ of the entire 


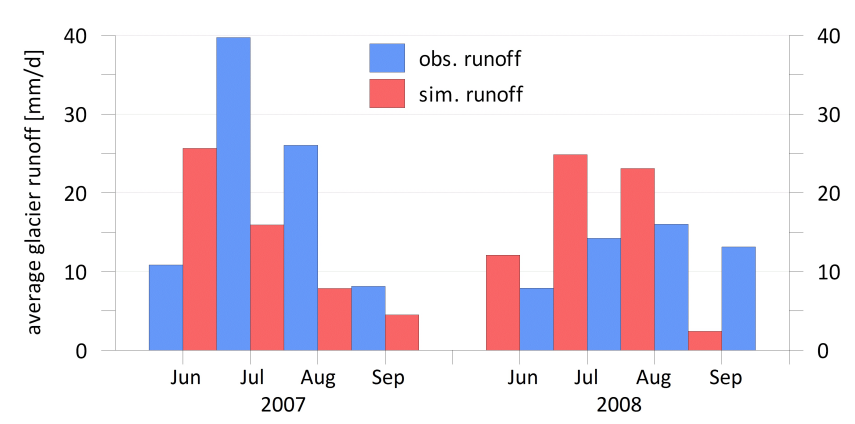

Fig. 5. Observed and simulation glacier runoff volumes.

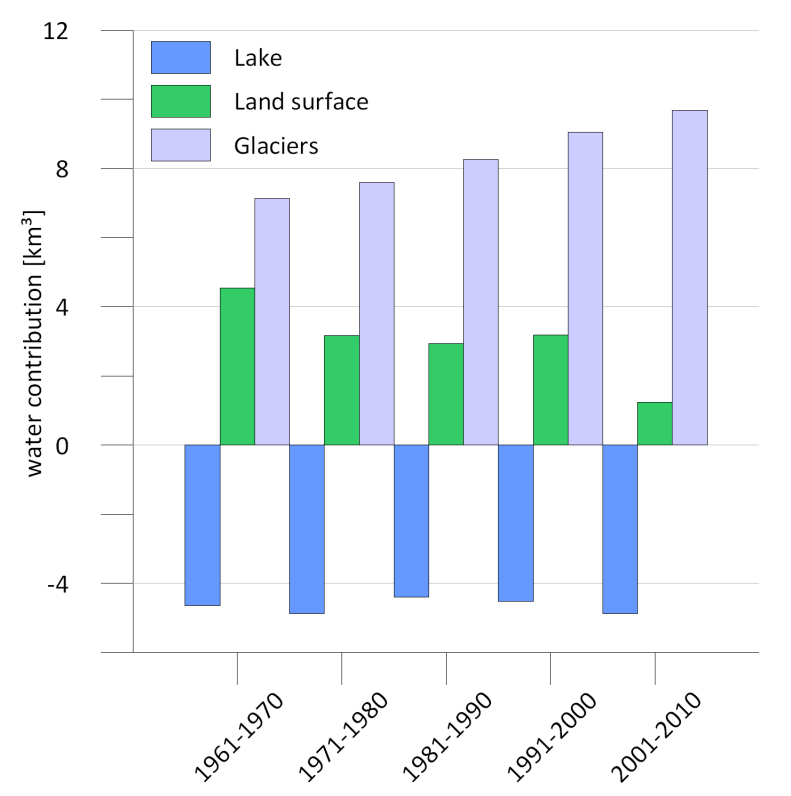

Fig. 6. Absolute water contribution to Nam Co lake in $\mathrm{km}^{3}$ from the three different land cover types.

basin is covered by glaciers. Figure 5 shows the observed and simulated runoff volumes from the glaciered regions. The discrepancy between measured and simulated runoff is partly caused by the fact that the model was run with projected climate data for the period of 2001 to 2010 which is different than the climate which was responsible for the observed runoff. Under this consideration a reasonable agreement of the simulated glacier contribution with measured runoff values from the outlet of the Zhadang glacier from 2007 and 2008 (Kang et al., 2008) could be stated.

Figure 6 shows the water in contribution in $\mathrm{km}^{3}$ for each decade and for each land cover type. The balance of the lake without inflows from land surface and glaciers is negative but is not showing a trend in the $50 \mathrm{yrs}$ period. The runoff generation from the land surface is relative high in the first wet decade and very low in the last decade primarily because of increasing evapotranspiration. The continuous rise in air temperature is causing a rising trend in the water contribution from the glaciered part of the catchment.

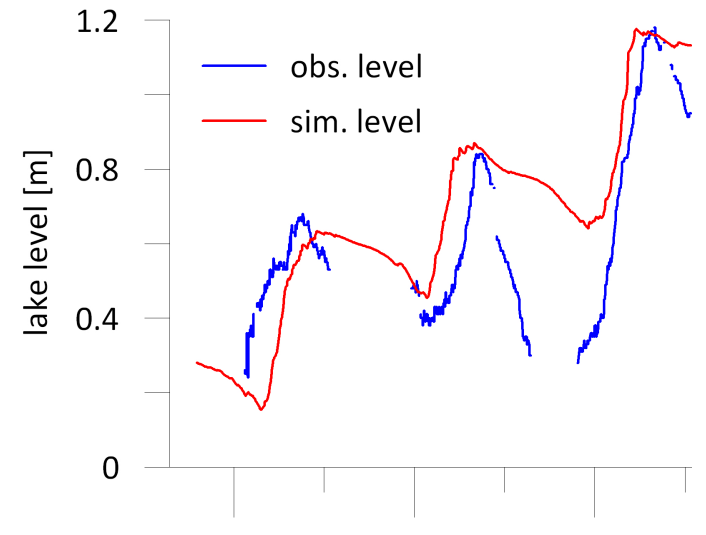

Mar.06 Apr.07 Jun. 08

Fig. 7. Observed and simulate lake levels in meter for 2006 to 2008.

The sum of all water inflow to the lake minus the lake evaporation for the $50 \mathrm{yrs}$ period resulted in an increase of the lake volume by $33.5 \mathrm{~km}^{3}$. This volume that is related to the average lake surface equals a lake level rise of about $17.5 \mathrm{~m}$ or $35 \mathrm{~cm} / \mathrm{yr}$. This is in good correlation with measurements and literature values. At the Nam Co the lake level is registered since 2005. From remote sensing information using a combination of various altimetry sensors an increase of the Nam Co lake level of about $2.5 \mathrm{~m}$ from 2000 to 2009 $(\approx 31 \mathrm{~cm} / \mathrm{yr})$ was estimated. The comparison between these observed values and the simulated lake level is shown in Fig. 7. The data gaps in the observed data occur primarily in times when the lake is frozen which is very often damaging the measurement equipment.

Figure 7 shows the general agreement between the observed and the simulated lake level. The discrepancies between the observation and the simulation are partly caused by the use of the climate projection data and the simplified model structure. However, the result shows that the magnitude is matched well by the model.

\section{Conclusions and outlook}

This study presented a hydrological system analysis and modelling of the basin of the lake Nam Co in Tibet aiming at a better understanding of the driving forces controlling hydrological processes in the context of a likely changing climate and monsoon dynamic in Asian high-altitude environments. Because of the insufficient availability of measured climate data to drive the model gridded data from a downscaled ECHAM5 data set was used. With that data set a reasonable simulation of the water balance could be achieved. It is unchallenged that the study contains a vast amount of uncertainty resulting from the input data and the model parameterisation and the model structure. Some minimal validation 
could be done by the comparison of the model results with the few observations of lake level changes and glacier melt runoff available for the catchment. In the near future the data situation will become much better as different research groups are investigating different aspects of the complex system of the Nam Co.

Despite the uncertainty the presented modelling study stressed the importance of the melt water runoff from glaciers which cover only $4 \%$ of the basin to explain the lake level rise which was observed in the last decades. In the $50 \mathrm{yr}$ long period the simulated melt water contribution from the glaciers to the lake was always higher than the contribution by runoff from the glacier free land surface. The trend analysis showed that the simulated glacier melt was the only variable which showed a significant positive trend during the simulated period.

Future work should concentrate on a reduction and quantification of the overall uncertainty by using climate data from other sources with a higher spatial resolution. Additional data for model validation which will be available in the future will help to analyse the model structure and the model parameterisation. To use the model for projection of the future the current glacier module needs to be extended to simulate not only glacier melt but also the glacier mass balance.

Acknowledgements. This project is funded in the DFG priority programme 1372 TiP - Tibetan Plateau: Formation-ClimateEcosystem. We thank two anonymous reviewers for their valuable comments which helped to improve the paper.

Edited by: A. Wahren, F. Tavares Wahren, and K.-H. Feger Reviewed by: two anonymous referees

\section{References}

Ahrens, B. and Dobler, A.: Downscaling of precipitation - the observational pitfall, in: 10th Plinius Conference on Mediterranean Storms, Nicosia, Cyprus, PLINIUS10-A-00101, 2008.

Allen, R. G., Pereira, L., Raes, D., and Smith, M.: Crop evapotranspiration: Guidelines for computing crop water requirements, FAO Irrigation and Drainage Paper 56, FAO, Rome, 1998.

Berry, P., Garlick, J., Freeman, J., and Mathers, E.: Global inland water monitoring from multi-mission altimetry, Geophys. Res., 32, L1604, doi:10.1029/2005GL022814, 2005.

Bianduo, Bianbaciren, Li, L., Wang, W., and Zhaxiyangzong: The response of lake change to climate fluctuation in north QinghaiTibet Plateau in last 30 years, J. Geogr. Sci., 19, 131-142, 2009.

Böhner, J.: General climatic controls and topoclimatic variations in Central and High Asia, Boreas, 35, 279-295, 2006.

Bormann, H.: Evaluation of hydrological models for scenario analyses: signal-to-noise-ratio between scenario effects and model uncertainty, Adv. Geosci., 5, 43-48, doi:10.5194/adgeo-5-432005, 2005.
Chen, F., Kang, S., Zhang, Y., and You, Q.: Glaciers and Lake Change in Response to Climate Change in the Nam Co Basin, in: CAS Annual Report of Nam Co Monitoring and Research Station for Multisphere Interactions, 3, Chinese Academy of Science, 51-59, 2008.

Chen, X., Zhang, X., and Li, B.: Influence of Tibetan Plateau on vegetation distributions in East Asia: a modelling perspective, Ecol. Model., 181, 79-86, 2005.

CNCCC: China National Report on Climate Change 2007, China National Committee on Climate Change, Tech. rep. No. 1, 2007.

Cyranoski, D.: The long-range forecast, Nature, 438, 275-276, 2005.

Eriksson, M., Xu, J., Shrestha, A., Vaidya, R., S., N., and Sandstrom, K.: The changing Himalayas: Impact of Climate Change on Water Resources and Livelihoods in the Greater Himalayas, ICIMOD, Kathmandu, 2009.

Harrison, J., Berry, P., Garlick, J., and Freeman, J.: Assessment of multi-mission radar altimeter performance over the Amazon basin, ESA Pub. SP-614, 2006.

Hock, R.: Glacier melt: a review of processes and their modelling, Prog. Phys. Geog., 29, 362-391, 2005.

Kang, S., Qin, D., Ren, J., Zhang, Y., Kaspari, S., Mayewski, P. A., and Hou, S.: Annual Accumulation in the Mt. Nyainqentanglha Ice Core, Southern Tibetan Plateau, China: Relationships to Atmospheric Circulation over Asia, Arct. Antarct. Alp. Res., 39, 663-670, 2007.

Kang, S., Gao, T., Zhang, Y., Yang, W., Yu, W., Chen, F., and Zhou, S.: Early Onset of Rainy Season Supresses Glacier Melt: A Case Study on the Zhadang Glacier, Tibetan Plateau, in: CAS Annual Report of Nam Co Monitoring and Research Station for Multisphere Interactions, 3, 30-43, 2008.

Kralisch, S. and Krause, P.: JAMS - A Framework for Natural Resource Model Development and Application, in: Proceedings of the International Environmental Software Society (IEMSS), Vermont, USA, 2006.

Krause, P.: Das hydrologische Modellsystem J2000: Beschreibung und Anwendung in grossen Flusseinzugsgebieten, Schriften des Forschungszentrum Jülich: Reihe Umwelt/Environment, Band 29, peer reviewed, 2001 (in German).

Krause, P.: Quantifying the Impact of Land Use Changes on the Water Balance of Large Catchments using the J2000 Model, Phys. Chem. Earth, 27, 663-673, doi:10.1016/S1474-7065(02)000517, 2002.

Krause, P. and Hanisch, S.: Simulation and analysis of the impact of projected climate change on the spatially distributed waterbalance in Thuringia, Germany, Adv. Geosci., 21, 33-48, doi:10.5194/adgeo-21-33-2009, 2009.

Liu, M. (Ed.): Physical Atlas of China, China Cartographic Publishing House, Bejing, 1998.

Maheu, C.: Water level fluctuations in the Plata Basin (South America) from Topex/Poseidon Satellite Altimetry, Geophys. Res. Lett., 30(3), 1143, doi:10.1029/2002GL016033, 2003.

Morrill, C.: The influence of Asian summer monsoon variability on the water balance of a Tibetan lake, J. Paleolimnol., 32, 273-286, 2004.

Penman, H. L.: Natural evaporation from open water, bare soil and grass, Proc. Roy. Soc. Lon. A Mat., 193, 120-145, 1948. 
Rupa Kumar, K., Sahai, A., Krishna Kumar, K., Patwardhan, S., Mishra, P., Revadkar, J., Kamala, K., and Pant, G.: High resolution climate change scenario for India for the 21st Century, Current Science, 90, 334-345, 2006.

Solomon, S., Qin, D., Manning, M., Chen, Z., Marquis, M., Averyt, K., Tignor, M., and Miller, H. (Eds.): The physical science basis, in: Contribution of Working Group I to the Fourth Assessment Report of the Intergovernmental Panel on Climate Change, IPCC, Cambridge University Press, Cambridge, 2007.

Thompson, L., Mosley-Thompson, E., Davis, M., Lin, P., Henderson, K., and Mashiotta, T.: Tropical glacier and ice core evidence of climate change an annual to millennial time scales, Climatic Change, 59, 137-155, 2003.

Treydte, K., Schleser, G., Helle, G., Frank, D., M., W., Haug, G., and Esper, J.: The twentieth century was the wettest period in Northern Pakistan over the past millenium, Nature, 440, 11791182, 2006.

Wang, B. and Ding, Q.: Changes in global monsoon precipitation over the past 56 years, Geophys. Res. Lett., 33, L06711, doi:10.1029/2005GL025347, 2006.

Wu, S., Yin, Y., Zheng, D., and Yang, Q.: Moisture conditions and climate trends in China during the period 1971-2000, Int. J. Climatol., 26, 193-206, 2006.

Wu, S., Yin, Y., Zheng, D., and Yang, Q.: Climatic trends over the Tibetan Plateau during 1971-2000, J. Geogr. Sci., 17(2), 141-51, doi:10.1007/s11442-007-0141-7, 2007.

Xu, Z., Gong, T., and Li, J.: Decadal trend of climate in the Tibetan Plateau-regional temperature and precipitation, Hydrol. Process., 22, 3056-2065, 2008.

Ye, Q., Kang, S., Chen, F., and Wang, J.: Monitoring glacier variations on Geladandong mountain, central Tibetan Plateau, from 1969 to 2002 using remote-sensing and GIS technologies, J. Glaciol., 52(179), 537-545, 2006.
Ye, Q., Yao, T., and Chen, F.: Response of Glacier and Lake Co variations to Climate Change in Mapam Yumco Basin on Tibetan Plateau during 1974-2003, Journal of China University of Geosciences, 19(2), 135-145, 2008.

You, Q., Kang, S., Tian, K., Liu, J., Li, C., and Zhang, Q.: Climatic Features on Mt. Nyainqen-tanglha, Tibetan Plateau, in: CAS Annual Report of Nam Co Monitoring and Research Station for Multisphere Interactions, 1, 16-23, 2006.

You, Q., Kang, S., Aguilar, E., Pepin, N., Flügel, W.-A., Yan, Y., $\mathrm{Xu}$, Y., Zhang, Y., and Huang, J.: Changes in daily climate extremes in China and their connection to the large scale atmospheric circulation during 1961-2003, Clim. Dynam., in press, doi:10.1007/s00382-009-0735-0, 2010.

Yu, G., Harrison, S., and Xue, B.: Lake status records from China: Data base documentation, Tech. Rep. 4, Max-Planck-Inst. f. Biogeochemie, Jena, 2001.

Zhang, Y., Kang, S., and Li, M.: Preliminary research of Climatic Features at Nam Co Station, Tibetan Plateau, in: CAS Annual Report of Nam Co Monitoring and Research Station for Multisphere Interactions, 3, 8-14, 2008.

Zhou, H., Zhou, L., Zhao, X., Liu, W., Li, Y., Gu, S., and Zhou, X.: Stability of alpine meadow ecosystem on the Qinghai-Tibetan Plateau, Chinese Science Bulletin, 51, 320-327, 2006 a.

Zhou, S., Kang, S., Liu, J., and Wang, S.: Preliminary results for hydrological observations in the Nam Co drainage area, in: CAS Annual Report of Nam Co Monitoring and Research Station for Multisphere Interactions, 1, 57-58, 2006b.

Zhu, D., Meng, X., Zhao, X., Shao, Z., Feng, X., Yang, C., Zheng, D., Ma, Z., Wu, Z., Wang, J., Wang, J., and Zang, W. (Eds.): On the Quaternary Environmental Evolution of the Nam Co Area, Tibet, Beijing, 312 pp., 2004. 